\title{
The Role of Human Capital in Improving the Competitiveness of Enterprises
}

\author{
Baigireyeva Zh.Z. \\ Kazakh Humanitarian Juridical Innovative University \\ Semey, Kazakhstan \\ zhanaruskaman@mail.ru \\ Niyazbekova Sh.U. \\ Moscow Witte University Moscow, \\ Russia \\ shakizada.niyazbekova@gmail.com
}

\author{
Borisova E.V. \\ Russian State Academy of Intellectual Property \\ Moscow, Russia \\ e.v.borisova@bk.ru
}

Ivanova O.S.

Moscow Witte

University Moscow,

Russia

mrs.ivanoff@yandex.ru

\begin{abstract}
This study examines the term "human capital", as well as its essence in modern conditions. In this regard, we have studied the concept of "human capital", given by various scientists and authors. The paper examines the question of the definition of "human capital" and on the basis of this study, the author's interpretation of the human capital concept, which to some extent is a novelty for science, is given. Human capital, fully developed and properly employed, can influence the achievement of enterprise results. In the form of an analytical table, the indicators of the human capital index in the country according to the world Bank are presented. It is noted that human capital is a set of human knowledge and skills that an enterprise can use to achieve its goals. All enterprises need human capital to function and achieve their goals. The role of human capital, its importance are of great importance in the management of human resources.
\end{abstract}

Keywords-human capital; resources; skills; abilities; society; potential; assessment

\section{INTRODUCTION}

The success of any nation in terms of human development depends largely on physical and human capital. The study of the term and definition of "human capital" by various authors allowed us to systematize this term and group it according to the following criteria: macroeconomics, labor productivity, investments, potential, definition of human capital, valuable capital, education, which contain more than two criteria.

\section{LITERATURE REVIEW}

The basis of the theory and methodology of the study were the works of Kazakh, Russian and foreign authors, experts in the field of human resource and human capital: A. Bovenberg [1], A. B. Maydirov [2], D. A. Seitkhozhin [3], O. Sabden [4], as well as sources and Internet resources.

\section{RESEARCH METHODOLOGY}

The following scientific research methods were used in the work:

* the method of deduction is used to understand the essence of human capital;
* the method of analysis was used to identify different interpretations of scientists;

* the synthesis method is applied to obtain generalized research results and General conclusions on the development of human capital;

* the comparison method is used to reveal the features and conditions affecting the development of human capital.

The practical significance of the work is that it can be used by students to improve the educational level in the study of topics on the development of human capital.

\section{RESULTS}

On the basis of studying the practice of functioning and formation of human capital and identifying a number of theories, we made an attempt to give the author's definition of the "human capital" concept: "Human capital-its meaning means the need to allocate sufficient resources in knowledge, skills and abilities."

A. L. Bovenberg noted that the structure of human capital includes communication skills, self-control and selfconfidence, emotional stability, the ability to allocate time, creativity, responsibility, the ability to accept a challenge, readiness for change [1].

Economist A. B. Maidyrova in his writings notes: "Human capital is considered as a set of all the productive qualities of man. In other words, human capital is the productive capacity of the individual, as we have repeatedly said above. Human capital implies that the productive capacity is an inherent personal property of man, which take the form of capital only as a result of a long historical development of relations about the qualities of the individual, in terms of commodity exchange at the present stage of development" [2].

D. A. Seitkhozhina noted that " Calculations of economic profitability of investments in human capital can be made not only empirically, but also taking into account real statistical information on the costs of education, taking, as an experimental, at least a small group of people. Of course, these 
observations will require painstaking, careful work for more than twenty years from the moment of a person birth to the beginning of his working life. In such studies, first of all, the state and business structures, without whose support they are impossible, should be interested. On the other hand, the rational meaning of this work is under great question, because it is not possible to "program" the life success of an individual even with the most large-scale investments in his human capital, i.e. an unambiguous result is not guaranteed" [3].

Kazakh economist O. Sabden considers the following: "the whole world is looking for new approaches to development, the leaders of the 8 and 20 leading States often gather, because accents change and we all have to reckon with the socio economic consequences of globalization, climate change, threats of terrorism and adapt to the new technological order. These are very complex tasks that require accelerated development of competitive human capital in Kazakhstan. In the conditions of modernization and diversification of the economy, only highly qualified personnel are able to effectively apply new technologies, use the latest equipment and produce competitive products. Stalin's words "cadres decide everything" should be interpreted in a new way in the XXI Century."

O. N. Melnikov reveals: "the Human capital we propose to consider as a set of inalienable property (in the form of his physical and intellectual resources that belong to human beings as personal property and which can be correlated with its "basic capital") and disposed of ownership, expressed in cost of physical and creative energy" [5].

The Encyclopaedia Britannica reveals the essence of human capital as follows: "Human capital, intangible collective resources possessed by individuals and groups within a given population. These resources include all the knowledge, talents, skills, abilities, experience, intelligence, learning, judgment and wisdom possessed individually and collectively, the aggregate of which is a form of wealth available to countries and organizations to achieve their goals" [6].

The world Bank has developed the Human capital Project, a global effort to accelerate the increase and improvement of investment in people for greater equity and economic growth. We study the issues of countries ' investment in human capital, early preparation of children for success and prosperity in the adult world and their health, whether there are barriers to human capital development that countries need to do to overcome them [7].

Human capital index of the Republic of Kazakhstan according to the world Bank table 1.

TABLE I. HUMAN CAPITAL INDEX OF THE REPUBLIC OF KAZAKHSTAN ACCORDING TO THE WORLD BANK FOR 2018 [8]

\begin{tabular}{|c|c|}
\hline \multicolumn{2}{|c|}{ Indicators of RK } \\
\hline The population & 18,04 million people \\
\hline GDP per capita & 25056 USD \\
\hline Income group & Upper Middle Income \\
\hline
\end{tabular}

Source: World Bank. The project of human capital. https://www.worldbank.org/en/publication/humancapital\#News [7]
Table 1 shows that according to the world Bank, the human capital index of the Republic of Kazakhstan by income group showed the Upper Average Income.

It should also be noted that in practice, the human Development index is a combined indicator characterizing human development in countries and regions of the world, which is compiled by the United Nations development Programme (UNDP) and is used in the framework of a special series of United Nations (UN) reports on human development [21].

\section{DISCUSSION}

At the first stage of the study, the following features were established. Human capital is available to create wealth for the economy or a private firm. In enterprises, human capital is available as a resource for public welfare. Human capital is developed and managed can be one of the most important determinants of economic and organizational performance.

The main source of production potential in the enterprise is the human capacity. It is therefore necessary to develop strategies to capitalize on the potential of this resource by developing training systems that will lead to an increase in the potential of human capital in the future.

\section{CONCLUSION}

Thus, on the basis of studying the practice of functioning and formation of human capital and identifying a number of theories, we made an attempt to give the author's definition of the "human capital" concept: "Human capital-its meaning means the need to allocate sufficient resources in knowledge, skills and abilities."

Thus, we studied the question of the "human capital" definition and on the basis of this study gave the author's idea of the concept of human capital, which to some extent is a novelty for science. In order to study the knowledge of human capital, we have only tried to display the essence of this subject in human representation and thinking. The systematization of various definitions of the "human capital" concept allowed us to more fully reveal the meaning of the term, to determine its role, forms and types.

Thus, the definition of our object of "human capital" study is an integral and very important part of the study since the concept is a deep knowledge of the study object reality. The concept concentrates the accumulated knowledge of science. Human capital acts as a resource. Human capital plays a vital role in the development and creation of new ideas and knowledge.

\section{References}

[1] Bovenberg A. L. The Life-course perspective and social policies: An overview of the issues. CESifo Economic Studies. 2008, vol. 54, 4.

[2] Maidyrova A. B. Human capital of the nation in the conditions of information society formation: methodological aspect. Astana. 2008, pp. 79

[3] Seitkhozhina D. Development of the concept of "human capital" in the system of market economic relations: production, investment, rate of return. Journal of the Eurasian Humanitarian Institute. pp. 83-91. 
[4] Sabden O. Development of human capital competitiveness in Kazakhstan and its legislative support. Collection of MNPK: Competitiveness of human capital-legislative support. 2011, pp. 13.

[5] O. N. Melnikov. Creative (creative) energy of the person as the main source of formation of economic and social relations in society / / Creative economy. 2007, 1, pp. 11-18.

[6] ENCYCLOPAEDIA Britannica. Electronic resource. URL: https://www.britannica.com/topic/human-capital

[7] Electronic resource. URL: Mode of access: https://www.worldbank.org/en/publication/human-capital

[8] M. Blaug. The methodology of Economics, or as economists explain. pp. 318.

[9] B. M. Genkin. Economics and sociology of labor: Studies for universities. 5th ed., additional: Norm. 2003, 416.

[10] C. A. Woodpeckers. Fundamentals of the theory of human capital. SPb. 1994, pp. 83.

[11] V. S. Efimov. Human capital of the Krasnoyarsk territory: foresight research-2030. Analytical report. Krasnoyarsk: Siberian Federal University. 2010, 126.

[12] Yu. A. Korchagin. Human capital and development processes at macro and micro levels. Voronezh: CIRE. 2004, 140.

[13] R. I. Kapelyushnikov, A. L. Lukyanova. Transformation of human capital in Russian society (on the basis of "Russian monitoring of economic situation and population health") Moscow: Liberal mission Foundation. 2010, 196.

[14] L. I. Abalkin. To use intellectual and economic potential for the future of Russia. Economist. 1999, 8, pp. 3-9.

[15] A. Smith. A study on the nature and causes of the wealth of Nations. Moscow: Sotsekgiz. 1956, pp. 490.

[16] G. Becker. Selected works on economic theory. M. 1992, pp. 35.

[17] Gavrilova E. N., Tolchinskaya M. N. Human capital as a factor of sustainable development of the country. Proceedings of the IX International scientific and practical conference "Regional problems of economic transformation: integration processes and mechanisms of formation and socio-economic policy of the region". 2018, pp. 525-527

[18] Zueva I. A. On the development of analysis and evaluation methods of regions socio-economic development. Bulletin of the Moscow University. S. Y. Witte. Series 1: Economics and management. 2017, 4(23), pp. 27-36. doi: 10.21777/2587-9472-2017-4-27-36

[19] Baranov D. N. Improvement of the workers engaged in sanitary maintenance of administrative, public buildings and adjacent territory labor standards calculation method. Vestnik of the Moscow University. S. Y. Witte. Series 1: Economics and management. 2017, 4(23), pp. 75-81. doi: 10.21777/2587-9472-2017-4-75-81

[20] Alexsandr S. Kuznetsov. Russian Professor's meeting. Russian Journal of Physical Education and Sport. 2019, 14(1), pp. 17-22. DOI: $10.14526 / 2070-4798-2019-14-1-18-24$

[21] Center for humanitarian technologies. URL: https://gtmarket.ru/ratings/human-development-index/humandevelopment-index-info. 